\title{
Correction to: Reconstruction or replacement? A challenging question in surgical treatment of complex humeral head fractures in the elderly
}

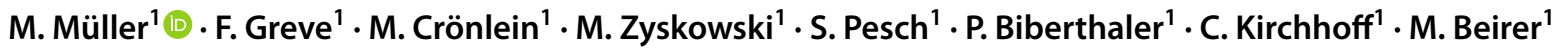

Published online: 24 November 2021

(c) The Author(s) 2021

\section{Correction to: Archives of Orthopaedic and Trauma Surgery https://doi.org/10.1007/s00402-021-04124-3}

The original version of this article unfortunately contained a mistake. There is a mistake in the abstract.

In abstract, second sentence of the result section should read as

63 patients were treated using the LCP fixation compared to 40 rTSAs.

The original article has been corrected.

Open Access This article is licensed under a Creative Commons Attribution 4.0 International License, which permits use, sharing, adaptation, distribution and reproduction in any medium or format, as long as you give appropriate credit to the original author(s) and the source, provide a link to the Creative Commons licence, and indicate if changes were made. The images or other third party material in this article are included in the article's Creative Commons licence, unless indicated otherwise in a credit line to the material. If material is not included in the article's Creative Commons licence and your intended use is not permitted by statutory regulation or exceeds the permitted use, you will need to obtain permission directly from the copyright holder. To view a copy of this licence, visit http://creativecommons.org/licenses/by/4.0/.

Publisher's Note Springer Nature remains neutral with regard to jurisdictional claims in published maps and institutional affiliations.

The original article can be found online at https://doi.org/10.1007/ s00402-021-04124-3.

M. Müller

michael.mueller@mri.tum.de

Department of Trauma Surgery, Klinikum rechts der

Isar, Technical University Munich, Ismaningerstraße 22,

81675 München, Germany 